\section{It is immoral to require consent for cadaver organ donation}

\section{H E Emson}

\section{No one has the right to say what should be done to their body} after death

in my opinion any concept of property in the human body either during life or after death is biologically inaccurate and morally wrong. The body should be regarded as on loan to the individual from the biomass, to which the cadaver will inevitably return. Development of immunosuppressive drugs has resulted in the cadaver becoming a unique and invaluable resource to those who will benefit from organ donation. Faced with the biological reality, the moral error of any concept of property in the body, and the quantitative failure of voluntary organ donation, I believe that the right of control over the cadaver should be vested in the state as representative of those who may benefit from organ donation.

How one regards the dead human body, the cadaver, is in part governed by one's familiarity with it. At the present time, very few people ever see a cadaver which has not in some way been altered after death, and even fewer touch, handle, deal in any way with the dead human body. In developed countries, death itself most frequently occurs away from the home, in an institution, under the supervision of professional caregivers. For most people, ideas concerning the cadaver, its nature, the proper way to deal with it, are formed under these conditions.

As a pathologist specialising in forensic pathology, for 50 years I have been at the other end of the spectrum of experience. In my daily work I have been privileged to examine the cadaver in all its stages after death from the immediate postmortem moments through all the stages of decomposition to bare bones. Working in a relatively small community, I have sometimes been charged with examining the body of someone I have known in life, which is never an easy task. These experiences have moulded my ideas as to what the cadaver is, what it represents, and how it should be treated. My beliefs are by no means unique, but I believe the experience which has formed them is unusual and because of this, important. Reading the works of ethicists who pronounce upon these matters, I wonder how many of them have ever viewed and touched a human cadaver, or seen a decomposing body.

Out of all this I have become what I understand is termed a dichotomist, one who believes that the body and soul are separate, different entities. I use the term "soul" for want of a better, not knowing a word which does not in some way carry implications of the soul's origin, nature, value, and destination. I wish to imply none of these, nor to intrude here my own religious beliefs. For the purposes of this discussion, the soul to me is a non-physical, immaterial entity which animates the body and gives it what we know as life. In knowing and experiencing a person, we cannot separate body and soul, because we always know them together. From the moment of birth until that of death they are inseparable and intertwined to form the person, the human being. At death the soul departs from the body-I have watched this occur-and here I express no beliefs whatsoever as to what happens to it at that point; where it goes, if anywhere, what its future is, if any. What is clear to me is, that without the soul, the body is not and can never again be a part of the person. The cadaver is not, what the body has been.

The body, on the other hand, is more easily defined and described. This, the physical entity animated by the soul, is formed of chemical elements and compounds, organised into tissues and organs, combined in a marvellous complexity and with the soul, it is the human person. In this combined state, the person is alive; without the soul, the body is dead, with all that implies. From the moment of conception the component parts of the body are formed from material drawn from the external physical world, in active interchange and dynamic equilibrium with the biomass, the sum total of living organisms on the planet, and with some of its inorganic matter. We study the human person from its earliest beginnings, through growth, differentiation, maturity, decline, disease, and death. The life of the metazoan animal Homo sapiens, as we know it-and this is only one of the ways of considering the human being-is finite; senescence starts with the zygote, and corporeal death is its inevitable end.

After death the human body decays, a process with which few are familiar and which excites revulsion which is both instinctive and learned. The instinctive part of this revulsion I think is easily explained, as an inherited reflex acquired by ancestral experience that rotten meat is not good to eat. Embedded very deeply in the nature of humanity there is another element to this, a belief that death is not the end of the soul and that the life of the body can somehow persist or be restored. This was expressed in the burial practices of the earliest humans, in the staining of bones of the deceased with red pigment as a symbol of continuing or resurgent life. Such practices have been elaborated by many different cultures, as in preservation and veneration of the bones of ancestors; burial with grave goods, food, slaughtered animals, and slaves, and mummification and embalming, to retain a simulacrum of continuing life, the last a common practice in many contemporary societies including our own. All these seek in some manner to deny the fact of death, or at the very least to delay its acceptance, to spread this as a process over a period of time, and to come to admit it gradually rather than as an instant blow at a single temporal point. Such practices often contrast oddly an expressed belief in an afterlife in a better world, with profound reluctance to leave this one. Many religions express belief in some form of "the resurrection of the body" but so far as I am aware, at the present time, this is only rarely interpreted as a strict physical reconstitution of its elements as at the moment of death. There is too much practical human experience for this, and however belief in a resurrection is interpreted, an element of symbolism is for most people inescapable.

However acceptance of death is denied or delayed, the human body is inexorably destined to decay as the beginning of a recycling process. Its constituent components are broken down by various means into simpler forms, and these in turn are recycled into the bodies of later generations of living things. We die and decay-or are burned - to come up again as wheat or roses, which in turn may form the bodies of future generations of people. Were this not so I would not be alive to write this, nor you to read it; the elements which might have formed us would all have been locked up in the indestructible physical remains of the first generation of living organisms. Decay is the inevitable and necesssary consequence of finite corporeal mortal life.

Viewed from this point, the human body can only legitimately be regarded 
as on extended loan from the biomass, to the individual of which it forms a part, and any view of it as property which can be owned and disposed of must be examined very seriously, questioned, and modified. Our culture accepts as a fundamental principle that while the body is animated by the soul, the person resulting from this union has a right to the preserved integrity of the body which is a necessary part of his or her total being. This is expressed in law, in our society, by prohibitions against killing, wounding, or even such minimal assault as threatening to touch the body without the person's consent. But how we should view the cadaver after death is a very different and much more questionable matter.

In that part of the ethics of our society which is expressed in law, there is no concept of the cadaver as property which may be disposed of for gain. The law, formed over a period of time before the possibility of transplantation existed, at present charges someone with the responsibility to dispose of the cadaver in accordance with society's customary practice and the requirements of public health, and gives this person powers to do so, but the cadaver is not his or her property. Until very recently there was no significant value in a human cadaver, and no legitimate use for it save its quantitatively very minor utilisation in dissection as a part of the training of physicians and surgeons. All this changed, recently, suddenly and dramatically, with the invention of immunosuppressive drugs which block the bodily rejection of transplanted organs and tissues, and make organ transplantation possible as a practical and effective treatment of human disease. The change is tremendous, unprecedented, unparalleled in our experience. The difference-for example, between chronic haemodialysis and kidney transplantation for the treatment of renal failure, is the difference between existence and life. From the strictly practical viewpoint, from being an object without intrinsic value destined only for disposal, the cadaver became at one leap a vital resource, something quite new in human experience. This quantum jump in technological capability brought with it, as all such advances inevitably do, totally new ethical problems. These in their turn can and must be tackled, and possibly solved, and faced with the unprecedented, it can only be done by fundamental examination of our basic beliefs, and their reconciliation with immutable physical facts.

One thing which must be considered at the very beginning, is the problem of immediacy. To be effective, an organ for transplantation must be removed as soon after death as possible. But it may be very difficult for relatives to accept that their loved one's body, maintained in a semblence of life by artificial respiration, is in fact dead and will obviously be so when the respirator is turned off. Added to this, there is acceptance of death as a process, not as an event; a fact which those close to the deceased come to accept gradually and which in its fullness may take years. Some progress towards reconciling these facts-for human emotions are facts with which we must deal-and resolving this dilemma, can be made when the death of an individual is known to be inevitable but can be postponed for a short time during which the family can come to terms with it. A great deal more could be done by the more gradual and diffuse processes of public education, but while the problem can be lessened, it inevitably will remain.

The cadaver has now become, to those who may receive its organs as replacement for their own which have failed, quite literally a source of continued life restored to something close to its fullness, and qualitatively different from existence maintained by mechanical means. In discussing this I shall limit myself to kidney transplantation, the commonest procedure which has become routine. Again, one wonders if some of the ethicists who pronounce on this, have ever met with and talked to patients who have experienced both existence maintained by haemodialysis, and life restored by transplantation. There is this real difference. This situation requires re-examination of basic beliefs; to whom does the cadaver "belong", and who should morally have rights to determine its disposal? To the deceased, it is something that has been a vital component of the person but now is no longer and is no more needed. To the bereaved family, it is a remaining part of the beloved deceased person, emotionally tremendously evocative, hallowed by individual experience and by centuries of belief and tradition. To the potential recipient of its donated organs, it is the very new hope of restored life.

I do not think that the concept of ownership or property in the human body is an accurate, defensible, or moral one, and I believe that the body should be regarded morally as on loan from the biomass to the individual of whom it is, during life, a part. Previously a matter of only academic interest, this is now of immense practical importance. I have no problem with the right of the individual to bodily inviolability during life; integrity of the body is a necessary part of integrity of the person, together with the individual freedoms that are commonly stated in charters of rights and the like. I am deeply concerned with the right of the person to govern disposal of their body after death, when separation of body and soul is irrevocably complete, and the individual is incapable of reconstitution. The person no longer exists, the soul has departed, and the individual who was but is no longer has no further use for the body which has been part of him or her during life. The concept of the right of a person to determine before death, the disposal of their body after death, made sense only when there was no continuing use for that body; it makes neither practical nor moral sense now, when the body for which the dead person no longer has any use, is quite literally a vital resource, a potential source of life for others. Another way of looking at the cadaver, is to liken it to a dress or a suit of clothes hanging in a closet, worn by the person during life, evocative of pleasant experiences and happy times, but now no longer needed by the one who has died and useful only as a memorial by the bereaved. If it can help to keep the living warm, should not this be done? Is this not both practically and morally, its right utilisation?

If this argument is correct, then it is even more morally unacceptable for the relatives of the deceased to deny utilisation of the cadaver as a source of transplantable organs. Their only claim upon it is as a temporary memorial of a loved one, inevitably destined to decay or be burned in a very short time. To me, any such claim cannot morally be sustained in the face of what I regard as the overwhelming and pre-emptive need of the potential recipient. It is particularly unacceptable when the deceased has during life expressed consent for cadaver organ donation, and still unacceptable if he or she has expressed no opinion. The need of the potential recipient, the benefit which may accrue to him or her, to me trumps and surpasses all other considerations. The proportionate benefit is too great to be subordinate to anything else. This can be expressed in a simple parable. A rich man has a loaf which he does not need, which he cannot eat, for which he has no use. To a poor man, starving, the gift of this loaf would be the gift of life itself. But the rich man says: "I will not give you this loaf; I will drop it on the dunghill to decay, or fling it in the fire to burn". This is to me a specific analogy of the denial of organ donation, of the conscious refusal to grant it. In many instances the denial is not conscious, a positive act, but a negative omission, a failure to consider and decide upon the possibility before it becomes real. It is commonplace that there is a great gap between the proportion of people in a society who favour organ donation, and the much smaller proportion who do anything about it.

In my opinion the human cadaver, at the point at which life departs, should become a resource for those who may benefit from donation of its organs. Our society has conspicuously failed to 
achieve this by voluntary means, and the increasing length of the queues for donated organs testifies eloquently to this failure. On the other hand, a majority of the community express their belief that cadaver organs should be used for transplantation. Faced with this contradiction and the dilemma so caused, it appears to be morally and practically necessary for society to act to overcome this failure, and this could best be done by making the human cadaver the charge and responsibility of the state, to determine its best disposition. Without going into detail, it might be done by establishing an organisation for this purpose, under the authority of the state but at "arm's length", very strictly separated from government and politics. The rights and responsibilities of disposal of the cadaver should be vested in this organisation. When the cadaver has been used, if possible, as a source of transplantable organs it may, if the family wishes, be reconsigned to their care, for such religious and social observances as they desire. Practically, this might be welcomed by many, as removing the necessity for an agonising decision by the family. Also practically, it is impossible for the family, in such circumstances, to be able to tell what has been done; after routine autopsy the body is reconstituted so that there is no outward sign, to ordinary observation such as that at an open coffin funeral or memorial service, that any examination has been performed. Legally, this might be regarded as an extension of the doctrine of Parens patriae, the assumption by the state of parental responsibility when this is necessary, on behalf of the persons benefiting from organ donation and transplantation. Morally, I regard the rights of the potential recipient, because of the benefits accruing, to be preemptive over all others.

In this situation, the idea of consent and its corollary, refusal are not morally applicable. One may be able to give or refuse consent to a procedure which affects oneself, but organ donation affects no one physically; no human person is involved as donor. To grant the right and power of consent to an individual who may be affected emotionally, is to elevate the possible emotional affect of one person, as more important than the physical life of another. The imbalance of benefit is too great to permit of this, and I find it morally unacceptable. To require consent for cadaver organ donation from the one of whose person in life the body is a part, is unacceptably to extend control of that body beyond legitimate limits. To require consent from the relatives of a previously living person is unacceptably to extend their control over matters where the good of others should be the predominant concern. The concept of consent in this situation is morally incorrect.

This having been said, in a society which places predominant value in autonomy, it may not be possible to enact in law what is morally correct. Should this matter ever attain the status of a legislative proposal, as it has in some countries, it might be a practical necessity to extend the principle of autonomy to a right to refusal of cadaver organ donation, to a living individual-to legitimise, in effect, the attitude of the rich man in my parable. To me this would be immoral, but it might be necessary to condone this limited immorality, commonly expressed as the right to opt out, or to refuse, to the individual. It would be a limited sacrifice to the much greater good.

J Med Ethics 2003;29:125-127

\section{Author's affiliations}

H E Emson; heemson@sasktel.net

\section{Death, us and our bodies: personal reflections}

\section{J Savulescu}

\section{We need to rethink our attitudes to the bodies of the dead in} order to increase our willingness to donate organs and tissues

M y father died aged 87 on January 20 , 1998. It was the day of his 42nd wedding anniversary. He been admitted to a major teaching hospital with jaundice of unknown origin. He died after a medical procedure and a delay in diagnosis and management of bleeding after the procedure. I believed it was important to understand why he had died and what the underlying cause of his jaundice had been. I requested an autopsy.

My father was not only the best father a person could have had, but my closest friend. The circumstances of his death were especially sad for me. I was on a plane while he was allowed to die of blood loss in intensive care over a period of hours, becoming progressively more delirious and experiencing the slow motion throes of death. I was told he had died while I was still in the air. My first thought was that I would never again see him or hear his deep chuckle. I would never again feel the gentle touch of his large hands. He would never see my daughter grow up as he had wanted to, playing, and laughing on the beach.

I have witnessed many autopsies. As medical students, we had to attend autopsy each morning at 8.30 am as a part of pathology in fourth year medicine. Before this, we had two years of anatomy dissection, probing every crevice of the formalin fixed human body. I learnt an immense amount from these activities. But I also knew how gruesome the autopsy is. I knew that an autopsy would mean that my father would be dismembered. But I had no hesitation in requesting an autopsy. Both I and my mother accepted that his body was dead. He would not be harmed. And important knowledge would be obtained.

\section{A. US AND OUR BODIES}

Let me say what my beliefs about the dead body are and why I hold them. There is a large philosophical literature on the relationship of mind and body to personal identity. I do not intend here to propose a philosophically robust or comprehensive account of personal identity. I outline here merely my personal reasons for holding the view that I do.

\section{Mind and body are different}

I believe we are different from and not identical with our body, at least in the morally relevant sense. Our body is a complex machine that supports our conscious and subconscious life. But it is our mental life which constitutes who we are, not the machine that supports it. I am my mind. My body allows my mind to express itself and shapes who I am, but mind and body are different.

This is consistent with several practices and beliefs:

\section{Brain death and organ harvesting}

Most people in the West accept a brain death definition of death. According to 
this definition, we are dead when our brain dies even though our body lives on. Organs and tissues can be taken because they continue to live after the brain has died.

\section{Withdrawal of medical treatment from brain damaged individuals}

There are several legal cases and many medical examples of life prolonging medical treatment being withdrawn from people who are permanently unconscious $^{1}$ or conscious but severely brain damaged. ${ }^{2}$ These practices are consistent with the view that what matters is our mental functioning, our mental lives, and that treatment which keeps our bodies alive (including our brain) can be stopped because mental life is so impoverished. For this reason, I do not believe "we" in the sense that matters are identical with our brains. The reason why we withdraw these medical treatments is because life in the significant sense has ceased. Our biography, as James Rachels once described it, has closed.

\section{Beliefs about the possibility of "continued existence" in other bodies}

In the recent science fiction film, The Sixth Day, Roger Spottiswoode, explores the concept of immortality through cloning. In this film, true cloning or copying of a person is perfected. This begins with "blanks" or drones stripped of all characteristics and DNA. DNA from the individual to be cloned is introduced into the drone and creates a physical replica of that person's body including their brain. This process differs from the cloning of an entire genome (which occurs with nuclear transfer) because scientists have also perfected a "cerebral syncoiding process"-whereby an exact picture is taken of the mind of the individual being cloned, which is then transplanted via the optic nerve of the blank. This reproduces all of the individual's memory and mental states up until that point including personal characteristics, learnt behaviours, and instincts.

Imagine that I have a tumour deep in my brain. It will grow slowly and kill me quickly in six months time. Up until that point, I will be asymptomatic. But there is no treatment and I will certainly die in six months. I have a choice-I can undergo the cloning process described in The Sixth Day. But there are two caveats. It must (for technical reasons) be done now and not later. And it will destroy my existing body. But it will create a replica without the tumour (let's assume the process can be tweaked to make subtle genetic changes). This body would die but it would be replaced by a replica with identical mental states. Would I survive the cloning process?

This is a complex question. But I would undergo the cloning process which destroys this body rather than continuing to live in this body for only six months. Even if "I" do not survive, I do not believe this matters. What matters is that my mental states persist, albeit supported by a different body. This suggests, to me at least, that what matters is not material bodily existence, but certain kinds of mental states.

I would still undergo this cloning process in this example if the clone was not an organic life form programmed by DNA and the syncoiding process, but a non-organic machine, providing the syncoiding process was accurate and the resulting being was conscious. This suggests to me that I am not identical with any particular physical substrate or support of my mental states. The physical substrate of our mental states is usually our brain but it could be something else. What matters is this mental life, not its physical basis.

This may seem to draw to sharp a distinction between mind and body-after all, we are embodied beings by our nature. Yet even on a less dualistic picture, there is an important distinction between embodied subjectivity (what matters) and the subjectless object. There is still an important distinction between the embodied mind and the body.

\section{Any afterlife cannot depend on how the dead body is treated}

Religions which include a belief in the soul or spirit which can be distinguished from the earthly body and which can exist in a disembodied state are committed to a view that what is essentially us or most important about us is different from our body.

Any kind of afterlife (if there is one) cannot depend on what is done to the dead body. This claim is supported by the widely differing practices concerning the dead-some religious believers bury the body, others burn it, and others eat it. Many people never have the chance to have religious ritual performed after death-they die at sea or in the mountains or are eaten by animals. It cannot be that God would disadvantage those unlucky enough, through no fault of their own, to be consumed by animals or who have died in some other tragedy.

(Indeed, if there is a God, and He is all loving, and our bodies do not belong to us but to Him, surely what He would want to happen to our organs and tissues is that they save the lives of those whom He loves but are suffering from kidney or heart failure?)

\section{We should show respect for the dead}

Burials (and other rituals) serve the function of showing respect for the dead. But it is only one way of showing respect for the dead.
We should show respect for the dead but how should we show such respect?

I felt that I should remember my father by being the kind of person he was. I felt I showed respect for him and the kind of person he was by giving to my children what he gave to me: love. I still have some of his ashes in a small urn. I will one day take these to a mountain where he used to climb in Romania and disperse them in the air. He asked me to do this. It will give me a time to reflect on his life and what he gave me. But this act is not as important as trying to be a better father. We show respect for the dead by thinking about them and helping their memory to shape our lives.

When my father died, I felt guilty at not being present at, and just prior to, his death. Guilty for not saying goodbye. But I decided to channel this guilt into to trying to help my children rather than suing the hospital and doctors for mismanagement or flagellating myself for my ( significant) failings. This is what he would have wanted. And this was what he lived for.

If we can show respect in these many ways, through many symbolic acts, it is best to remember the dead in and through the living, whose lives can be made better by the acts of remembering. Organ and tissue donation to others symbolises the greatest goodness of a person-the capacity to make others's lives better.

\section{B. SOURCES OF ORGANS AND TISSUES}

Tissues and organs from humans have enormous potential value for research, transplantation, education, and training. There are several sources of organs and tissues:

1. the living, where the tissue is taken solely for the benefit of others (live kidney or liver transplantation)

2. the living, where the tissue is redundant to procedures (diagnosis or management) which were performed in the interests of the patient (for example, discarded appendix or colon)

3. the dead person.

\section{ETHICAL ISSUES}

When should we use tissue or organs from one person to benefit others?

There are two approaches: (1) the autonomy centred view; (2) the beneficence centred view. ${ }^{3}$

\section{The autonomy centred view}

Liberal societies place importance on people freely forming and acting on their own conception of how their life should go (and end). "Autonomy" comes from the Greek, "autos" "nomos" meaning self rule or self determination. The importance given to the freedom and 
values of individuals is captured in the concept of respect for autonomy. In the case of living people, this is thought to imply that (1) body parts can only be used with the consent of the individual. And in the case of dead people that (2) organs can only be taken from dead people if they consented to their removal prior to death.

What should be done if the person did not express a desire about the use of her organs after her death? Here we must make a determination of what she would have wanted, and what is most consistent with her values. If a doctor used her organs, and this conflicted with the deceased patient's values, then on one view, that patient's past autonomy is not respected. But likewise, if doctors do not use her organs, and the deceased patient would have wanted them used, then we also fail to respect his past values and autonomy by not releasing the information.

Thus, even if we adopt an autonomy centred view and give weight to the deceased person's past values and desires, it is important to make an evaluation, based on the evidence available, of whether this person would have wanted her organs used after death. To fail to take a person's organs who would have wanted them used for medical purposes is to fail to respect that person's autonomy, to fail to respect that person's values, even if families do not want those organs or tissues used.

More controversially we could reject (2), the claim that respecting autonomy requires we satisfy the past desires of the dead. We could claim that, when we die, we cease to exist as autonomous beings and our past desires are of no direct relevance to self determination after our deaths because there is no self. This is a radical view that would involve disregard of the desires of the dead-I will not pursue it here.

\section{The beneficence centred view}

Beneficence is doing good for other people. A beneficence centred view states that we should use organs and tissues if doing so does more good than harm, regardless of people's desires. This raises the complex philosophical question in the case of using organs and tissues from dead people of whether the dead can be harmed. On some views, the dead cannot be harmed. On these views, there would be strong obligations to taking organs and tissues from the dead.

Most people accept a weak moral obligation of beneficence. According to this weak version, which can be called a duty of easy rescue, an individual (living or dead) has an obligation to give up for use some tissue or organ only when the harm to that individual is minimal, and the benefit to others is great. If we do not have a moral obligation to save another person's life when it is of no cost to us, what do we have moral obligations to do?

This is consistent with the way in which the doctor/patient relationship has come to be viewed. The standard view is that doctors should act in their patient's interests. There are, however, many statutes that require disclosure of confidential information in the public or other people's interest. ${ }^{4}$ Breaching confidentiality is justified in some cases in the public interest-for example, outbreaks of infectious diseases and notifiable diseases, or when identifiable individuals are at grave risk. An example of the latter is when a doctor knows that an HIV positive patient is putting a partner at risk without the partner's knowledge and the patient refuses to practice safe sex or inform the partner. The General Medical Council has provided specific guidance for doctors with regard to HIV infection and confidentiality. In essence these allow the doctor to breach confidentiality.

Thus, this position justifies the use of organs and tissues when there is minimal harm to the person. Provided that confidentiality is protected, this would mean that redundant organs and tissues could be used. If one believes, as I believe, that the dead cannot be harmed, it would justify the use of organs and tissues from the dead.

\section{The moderate position}

The implications of the beneficence centred view, even in its most moderate version, can be extreme. A more moderate position combines both the autonomy centred and beneficence centred views as the moderate position. According to this, doctors should use organs and tissues if:

- there is a significant interest in that tissue or organ

- there is no good reason to believe that the person had or would have objected to its use

- using the organ is not against the person's interests.

\section{IMPLICATIONS}

Organs and tissues are special. In life, they allow us to be people. But we are not the same as our bodies or body parts. There is no intrinsic value in organs and tissues. We should change the significance we attach to body parts. What matters is people. Body parts are valuable only and in so far as they make people's lives go better. And when mental life is absent or grossly diminished, we cease to exist in any significant sense. For that reason, I believed autopsy did not harm my father, though it mutilated his body. This kind of view of personal identity has other implications.

Many people should be attracted to the moderate position, which constitutes an autonomy centred weak obligation of beneficence. Such a position implies we have moral obligation to give organs and tissues after death or medical procedure, provided no one is significantly harmed and there is no reason to believe the person objected or would have objected to such use. If one divides mind and body, the moderate position supports an opt out system of organ donation after death (see the paper by English and Sommerville $e^{5}$ 147). Since we are not harmed by the removal of organs or tissues, and these are of great benefit to others, there is an obligation to donate these or to register an objection, or at least there is no good reason to fail to donate these tissues.

It also supports encouraging people to complete advance directives or organ donor cards, specifying whether they do have an objection to organ donation.

How can we encourage people given the current system where there are ever greater legal requirements to obtain consent for organs and tissues to be used for the benefits of others?

There are two things we could do.

1. Commerce in tissues/organs: what matters is how well our lives go, not whether we have two kidneys or one. When we realise that our bodies are not constitutive of us, are merely the means for us to effect our lives, objections to the sale of organs wither. Several articles in this issue argue in favour of the sale of organs and tissues. ${ }^{6-9}$

2. Tax breaks for organ/tissue donors. We reward those who donate to charity by allowing them to claim such donations in their tax returns. I believe we should have a mandatory system of registration-for example, on a driving licence-of willingness to donate organs and tissues after death. We should offer tax breaks to those who contribute to the public good of organ and tissue donation. If we reward people for donating money to others, we should reward those who are willing to donate their organs and tissues for the benefit of others.

Where a person has consented to organs and tissues being used for the benefit of others, that wish must be respected regardless of family preferences for the fate of the body. To fail to respect such wishes is wrong for two reasons:

1. it fails our obligation to respect the autonomy of people

2. it fails the most basic duty of rescue, to benefit others.

If we believe that what matters is our mental state, then we should review the rule that we can only take organs from those who satisfy brain or cardiorespiratory criteria for death (see the papers by Zamperetti et $a l^{10}$ and by Bell ${ }^{11} \mathrm{p} 176$ and 182). This is called the "dead donor 
Summary: Changing practices towards organs and tissues

- Duty of easy rescue-the moral obligation to give organs and tissues after death or when redundant.

- Adopt an opt out system for organ/ tissue donation

- Tax breaks for organ/tissue donors

- Respect the wishes of those who choose to donate

- Encourage advance statements about organ/tissue donation

- Allow commerce in tissues/organs

- Review the dead donor rule

rule". Since I believe we die when our meaningful mental life ceases, organs should be available from that point, which may significantly predate brain death. At the very least, people should be allowed to complete advance directives that direct that their organs be removed when their brain is severely damaged or they are permanently unconscious.

\section{CONCLUSIONS}

I remember seeing an exhibition at the Taiwan Museum depicting how Tibetan Buddhist monks showed respect for their dead. They ate parts of the body and made objects of art from others. One picture depicted a person blowing a trumpet made from a tibia from a deceased family member.

This is only one of the many ways we can show respect for those we loved. But surely the best way is through remembering their qualities to benefit others. If we change the way we think about our bodies and the bodies of those we love, and understand how beneficial body parts can be to the lives of others, an enormous amount of good could be done at no cost. It is time to rethink our beliefs about organs and tissues, and the bodies of the dead.

\section{J Med Ethics 2003;0:127-130}

\section{Author's affiliations}

\section{REFERENCES}

1 Airedale NHS Trust $v$ Bland [1993] 1 All ER 821; Frenchay NHS v S [1994 2 All ER, 403, 411-13.

2 Re Dinnerstein (1978) 380 NE 2d 134 (App CtMass)-US: Clarence Herbert 1981 -US Annas GJ. Nonfeeding: lawful killing in CA, Homicide in NJ. Hastings Cent Rep 1983; 13:19-20; In the Matter of Claire Conroy (1985) 486 A 2d 1209 (NJ Sup Ct) In the Matter of a Ward of Court [1995] 2 ILRM 401; In the Matter of G, In the High
Court of New Zealand Registry M126/96. From the Canterbury District Law Society, 6/1/97. Hearing 6 December 1996, Judgment 13 December 1996.

3 Savulescu J, Skene L. Who has the right to access medical information from a deceased person? Ethical and Legal perspectives. J Law Med 2000;8:81-8.

4 Notifiable Diseases [Public Health (Control of Diseases) Act 1984]; Misuse of Drugs Act 1973; Abortion Act 1967; Births and Deaths Registration Act 1953; Road Traffic Act 1988; Human Fertilisation and Embryology Act 1990; NHS Venereal Diseases Regulations 1974; The Children's Act 1989; Human Organ Transplants Act 1989, and Prevention of Terrorism Act (Temporary Provision) Act 1989.

5 English V, Sommerville A. Presumed consent for transplantation: a dead issue after Alder Hey? J Med Ethics 2003;29:147-52.

6 Erin CA, Harris J. An ethical market in human organs. J Med Ethics 2003;29:137-8.

7 Radcliffe Richards J. Commentary. An ethical market in human organs. J Med Ethics 2003;29: 139-40.

8 Savulescu J. Is the sale of body parts wrong? J Med Ethics 2003;29:138-9.

9 De Castro LD. Commodification and exploitation: arguments in favour of compensated organ donation. J Med Ethics 2003;29: 142-6.

10 Zamperetti N, Bellomon R, Ronco C. Defining death in non-heart beating organ donors. J Med Ethics 2003;29:182-5.

11 Bell MDD. Non-heart beating organ donation: old procurement strategy-new ethical problems? J Med Ethics 2003;29:176-81.

\section{Organ procurement: dead interests, living needs}

\section{John Harris}

\section{Cadaver organs should be automatically available}

$\mathrm{T}$ he shortage of donor organs and tissue for transplantation constitutes an acute emergency which demands radical rethinking of our policies and radical measures. While estimates vary and are difficult to arrive at there is no doubt that the donor organ shortage costs literally hundreds of thousands of lives every year. "In the world as a whole there are an estimated 700000 patients on dialysis . ... In India alone 100000 new patients present with kidney failure each year" (few if any of whom are on dialysis and only 3000 of whom will receive transplants). Almost "three million Americans suffer from congestive heart failure ... deaths related to this condition are estimated at 250000 each year . . 27000 patients die annually from liver disease .... In Western Europe as a whole 40000 patients await a kidney but only . . . 10000 kidneys" become available. Nobody knows how many people fail to make it onto the waiting lists and fail to register in the statistics. "As of 24th November 2002 in the United Kingdom 667 people have donated organs, 2055 people have received transplants, and 5615 people are still awaiting transplants." ${ }^{2}$

Conscious of the terrible and unnecessary tragedy that figures like these represent I have been advocating for more than 20 years now some radical measures to stem this appalling waste of human life. The measure which is the subject of Hamer and Rivlin's paper $(\mathrm{p} \mathrm{196})^{3}$ concerns the automatic availability of all cadaver organs-a measure, which I first advocated publicly in $1983 .{ }^{4}$

\section{THE AUTOMATIC AVAILABILITY OF DONOR ORGANS}

We need to begin by being clear about just what it is I propose and why. At the moment in the United Kingdom we have an "opting in" system (donor cards) and there has been some pressure for us to move to an "opting out" system which is sometimes called "presumed consent". In this latter case organs would be available for transplantation unless the potential donor had registered his or her objections to donation prior to death. Both of these systems give central place to the individual's right to determine what happens to his or her body after death. I challenge this assumption. I suggest that consent is inappropriate as a "gatekeeper" for cadaver donations. ${ }^{5}$

All the moral concern of our society has so far been focused on the dead and their friends and relatives. But there are two separate sets of individuals who have moral claims upon us, not just one. There is the deceased individual and her friends and relatives on the one hand, and the potential organ or tissue recipient and her friends and relatives on the other. Both have claims upon us, the claims of neither have obvious priority. If we weigh the damage to the interests of the deceased, and her friends, and relatives if their wishes are overridden against the damage done to would be 
recipients and their friends and relatives if they fail to get the organs they need to keep them alive, where should the balance of our moral concern lie?

If we address this question seriously we must think what each group stands to lose. The cadaver donor stands to lose very little, but not nothing, as Hamer and Rivlin rightly say. She is dead and past being harmed, except in the relatively trivial sense in which people possess interests that persist beyond their death and which can in some sense be harmed. ${ }^{6}$

We must remember that while the organ donor may have a posthumous preference frustrated, (more of which anon) and her friends and relatives may be distressed and upset, the potential organ recipient stands to lose her very life and her friends and relatives will have grief to add to their distress.

\section{CADAVER ORGANS SHOULD BE AUTOMATICALLY AVAILABLE}

One solution to the problem of sensibilities would, I have suggested, be to provide for the automatic or mandatory availability of donor organs. If this were done, of course only as a result of democratic acceptance of the idea, neither relatives nor the former "owners" of the cadavers need be consulted about their disposal. This would remove the necessity for asking permission at a sensitive moment and hence the moral objections to so doing. People would, I believe, soon get used to the idea, particularly if there were to be a concerted campaign of education and argument.

Indeed it seems clear that the benefits from cadaver transplants are so great, and the harms done in going against the wishes of those who object so comparatively small, that we should remove altogether the habit of seeking the consent of either the deceased or relatives. This would be another example of a small but significant class of public goods, participation in which is mandatory.

\section{MANDATORY AND VOLUNTARY PARTICIPATION IN PUBLIC GOODS}

It is widely recognised that there is clearly sometimes an obligation to make sacrifices for the community or an entitlement of the community to go so far as to deny autonomy and even violate bodily integrity in the public interest and this obligation is recognised in a number of ways. $^{7}$

All British citizens between 18 and 70 are liable for jury service: those over 65 may be excused if they wish. They may be called, and unless excused by the court, must serve. This may involve days, but sometimes months of daily confinement in a jury box or room, whether they consent or not. Although all are liable for service, only some, however, are actually called. If someone is called and fails to appear they may be fined. Most people will never be called but some must be if the system of justice is not to break down. Participation in or facilitation of this public good is mandatory.

There are many senses in which automatic cadaver donation involves features relevantly analogous, in particular to jury service. But the clearest case is that of postmortem examination. The courts can order examinations without any consent being required and despite the fact that these involve interference with the dignity of a dead body and the removal of organs. Of course postmortem examinations are not usually ordered simply out of curiosity, there are public safety and public policy considerations. It is important that the cause of death be known in case the same cause represents a further danger to the community, whether that danger be in the form of a disease or contagion, or in the form of a possible murderer at large. ${ }^{8}$ But again related but more powerful considerations weigh in favour of mandatory cadaver transplants.

It therefore seems appropriate to consider mandatory availability of cadaver organs. The public interest in saving the lives of fellow citizens at risk is at least as urgent and as important as the public interest which justifies court ordered postmortem examinations. Moreover it is, I suggest, less damaging to civil liberties and less compromising of individual autonomy than-for example, compulsory jury service. (I say nothing of compulsory military service, which is widely accepted in many countries.) For although both jury service and postmortem examinations have justifications in terms of protection of the lives and liberties of citizens, so of course does the automatic availability of cadaver organs.

\section{THE HAMER AND RIVLIN OBJECTIONS}

This then is the proposal to which Hamer and Rivlin object. They have two main grounds of objection. Before coming to these, however, we should just consider a preliminary claim, namely that "both objections stem, essentially, from the fact that utilitarianism denies freedom to moral agents: . . because it requires that they be used as means to another's end if the consequences are sufficiently good . ..." I will not be drawn into defending utilitarianism because my position is not straightforwardly utilitarian, but this suggestion is simply false. All ethical systems require that the freedom of people be subordinated to moral considerations if the reasons for so doing are sufficiently important or, as Hamer and Rivlin suggest, "if the consequences are sufficiently good". If this were not the case there could not be laws against murder nor-for example, requiring the compulsory wearing of seat belts in cars. The only remaining question is when the moral considerations for restrictions on liberty are sufficiently compelling; and this is the subject of the disagreement between us. Utilitarianism gives moral agents reasons to make certain choices, to say it denies them freedom is, in the words of a famous utilitarian, "nonsense upon stilts".

Hamer and Rivlin then elaborate two main objections to my proposal that cadaver organs be automatically available for transplantation. They suggest that I have ignored or deny the possibility of the dead having what they call "surviving interests". Unfortunately Hamer and Rivlin have relied for their understanding of my position on two very recent internet sources. One a live interview, the accuracy of which is doubtful, another from "midwalesonline". For the record I do not deny that there are such things as "surviving interests" or, as I termed them more than 10 years ago, "persisting interests". The issue is whether these interests are sufficiently strong to constitute plausible objections to sacrificing such interests to save the lives of those who need transplants.

\section{PERSISTING OR "CRITICAL" INTERESTS}

I have never doubted that there is a real sense in which individuals may have some interests that survive their death and hence there are some senses in which an individual's interests are still in play after death. 'While such interests deserve some respect, they are, I have argued, relatively weak ${ }^{10}$ when compared with the interests of living persons who exist to be harmed in person by the neglect of their interests. The appropriate principle should be that their wishes when alive as to affairs after death should be respected, (out of courtesy so to speak $)^{5}$ subject to reasonable demands of public interest.

It is tempting to think of those sorts of interests we have termed "critical" or "persisting" as contrasted with so called "experiential" interests-interests that we are aware of and aware of being either served or not served by what happens. Ronald Dworkin highlights this particular contrast, defining experiential interests as things we have an interest in because we like the experience of doing them. Critical interests on the other hand are those "interests that it does make . . . life genuinely better to satisfy". ${ }^{11}$

There is, however, another distinction which has some importance and that is whether particular interests are "person affecting" in the sense that their satisfaction or frustration would be good or bad 
for the person whose interests they are. It is widely accepted in contemporary ethics that "the part of morality concerned with human wellbeing should be explained entirely in terms of what would be good or bad for those people whom our acts affect". ${ }^{12}$ So although what happens to my children, or my body after my death, can involve my critical interests in the sense that it contributes both to the success or failure of my life as a whole and to whether it has achieved the meaning with which I had hoped to endow it, such things are not person affecting, they are not good or bad for me, they do not affect my wellbeing because "I" no longer exist. I am simply not there to be affected one way or the other, my wellbeing cannot be affected because I am no longer "a being". In short, though in a sense my interests persist, " $I$ " do not.

Some, but not all, critical interests will be person affecting, all experiential interests will, but person affecting is what counts when we are principally concerned with human wellbeing, or with personal rights or interests. Posthumous interests are never person affecting nor are posthumous frustrations of autonomous choices.

I believe that although there are such things as persisting interests they are, of necessity, less significant than person affecting interests. In Wonderwoman $\theta$ Superman ${ }^{13}$ I put the point like this:

It is I admit, hard work imagining why one should separate harming someone's interests and harming that someone. But the point of doing so is perhaps this: if we damage the environment irreparably today, this will harm the interests of future generations but it will not harm individuals as yet undifferentiated until they come into being. It harms their interests now and them only when they exist. Similarly the interests of actual people persist after their deaths. When they are alive you can harm (or benefit of course) both the individual and her interests. Once she is dead only her interests remain to be harmed.

This is why the damage to the persisting interests of the dead must be set against the damage to the persisting interests of the living, damage which, in the case of the living, also affects the persons whose interests they are. This double damage will for all practical purposes always give the edge to the interests of the living.

While the life of a person then is affected by frustration of interests the dead are not affected "in person" by this. Note that it is not a question of experiential versus critical interests but person affecting versus persisting interests. Person affecting considerations affect living persons whether or not they experience them in the sense of being aware of them. I am affected in personfor example, by malicious gossip; it is person affecting even if I remain unaware of it.

Since the dead subject has ceased to be the subject of person affecting morality, since she has neither autonomy rights nor interests to protect and only some rather attenuated persisting or critical interests if any, her wishes do not have the primacy that rights and person affecting interests can claim in moral argument. They cannot function, in Dworkin's famous terminology, as "trumps". ${ }^{14}$ Equally the wishes of parents or next of kin lack their normal central role. Next of kin or "guardians" are called upon to make decisions for the incompetent only on the assumption that these represent safeguards of best interests or sometimes, (I believe erroneously) ${ }^{15}$ as interpretations of the wishes of the incompetent individual. Here again the wishes of next of kin, guardians or other relatives as to what happens to their deceased relation cannot have the primacy that they have traditionally been accorded, in that they represent neither the expression of the rights nor the person affecting interests of the deceased. Again they cannot function as "trumps" in moral argument.

We should note that there is a sense in which what happens to my body after death is person affecting; it is just that it is not me who is the affected person. The things that happen to my body after death are person affecting in the sense that they affect the persons who will benefit from the organs or tissue that could be harvested from me and indeed the persons who are distressed by the tissue being collected retained or used.

So that when Hamer and Rivlin say: "It is open to Professor Harris to concede that the dead have surviving interests ... imposing moral restrictions upon our treatment of them, but to deny that this means that we cannot use them as donors against their will", they are quite right, it is not only open to me, I have said precisely this. Hamer and Rivlin have spent the main part of their paper articulating a conception of posthumous interests that I (and many others) have also articulated and in establishing a point that I concede but, which I have argued has scant moral force when set against the harm that overriding such interests might prevent.

Against this final point Hamer and Rivlin say:

We do not know whether an interest in posthumous bodily integrity should trump an interest in continued life las a minor objection, even assuming we agree with Harris that such a comparison of "harms" is necessary we are at a loss to think of a way to go about it, except in a very rough intuitive manner).

I am at a loss to understand their problem here. We always have to compare the moral importance of different sorts of interests. To take a hackneyed example already mentioned, we have to decide whether the freedom to choose not to wear seat belts in cars can be compared with the harm of loss of life or serious injury and the costs of this to the health care system of a nation state. Equally we have to decide whether the harm to a person's posthumous interests of imposing a tax in the form of so called "death duties" compares with the benefits of the good that the revenue raised will do. It may to some extent be rough and ready, but we try to assess the moral, political, and social importance, the "strength", of the respective rights and interests in play. We do this partly by asking the sorts of questions I have been asking. What does the individual whose rights or interests are sacrificed stand to lose compared with what will be gained by the sacrifice of those rights or interests? Even when the rights or interests in play are trumps-very strong rights indeed, it is still accepted that some weight of countervailing interests might be enough to warrant their disregard. We do this in medicine every day. We compare the harms of surgery, (scarring, pain, the risks of anaesthesia etc) with the gains from the surgery; or we compare the harms of chemotherapy with the expected gains in terms of remission. We do this even when we cannot be assisted by the wishes of the patient (because they are incompetent or unconscious). What would we say of a medical team that lamely pleaded "we are at a loss to know how to make this calculation"?

In fact Hamer and Rivlin are considerably overstating the difficulties here. There is in fact remarkable objectivity (by which I mean convergence or consensus in judgments) about the relative severity of harms. Particularly, there is almost universal agreement that death is usually the worst harm than can befall a human person who wants to live: fates "worse than death" are rarely suffered outside Victorian melodrama. Thus it is relatively easy to see that rights or interests would have to be extremely powerful to warrant upholding such rights or interests at the cost of the lives of others. I have argued (not simply suggested or intuited) that the interests involved after death are simply nowhere near strong 
enough, and I have heard nothing from Hamer or Rivlin to persuade me (or I believe any rational person) that there is much merit in a contrary view, in a view which would sacrifice lives to the protection of a desire not to donate organs.

So since Hamer and Rivlin state: "our argument against the moral permissibility of removing organs against premortem wishes does not rely only on the surviving interests idea", let's see what else they've got.

\section{NO MORAL SPACE}

The first of two arguments with which they supplement their main argument considered above, they call "the nonmoral space" argument. Basically the argument is:

By requiring that our concern for those in need of organs leads us to remove organs from the dead against their wishes, Harris's theory is too demanding. Utilitarianism makes no distinction between causing an event and allowing it to happen when it was physically within our power to prevent-we are as responsible for outcomes which we fail to prevent when it is in our power to do so as we are for events we straightforwardly cause. . . . He says that those who refuse to allow their organs to be used "would have to explain why they would wish other people to die rather than have their organs used" and suggests it is "surely far from clear that people are entitled to conscientiously object to practices that will save innocent lives".

Hamer and Rivlin make great play of the idea "that those who refuse to allow their organs to be used "would have to explain why they would wish other people to die rather than have their organs used". This they get from a live interview reported on the web. I do not believe I used the phrase "would have to explain why they would wish other people to die" but if I did, it was an off the cuff rhetorical flourish and does not represent my views. It certainly does not convey any argument that I have ever produced in print. I have always argued strongly for the irrelevance of "intention" when ascribing moral responsibility. To me it matters not a jot whether people "intend" or "wish for" what they bring about. What matters morally is what people deliberately and knowingly do or fail to prevent. ${ }^{16}$ That said, Hamer and Rivlin's main point is still good, for I stand by the suggestion that it is "surely far from clear that people are entitled to conscientiously object to practices that will save innocent lives" with the missing proviso "when the costs to them are insignificant in comparison with the gains to others". So when Hamer and Rivlin say all "the person who refuses to donate aims at, it seems to us, is having their body remain whole after their death" they are right. My point is that it is surely implausible to think that having one's body remain whole after their death is an objective anyone is entitled to pursue at the cost of other people's lives! It is implausible to the point of wickedness, not least because the objective is irrational and impossible of achievement.

As I recently argued in a related context:

The human body cannot for long remain intact after death. It is perishable and will, as has been chronicled in art and literature since time immemorial, inevitably decay, disintegrate and turn to dust, or worse . . .. Shakespeare, as ever, tells it like it is. In this conversation between Hamlet and Horatio the inevitable fate of the dead is made both vivid and comic.

Hamlet: Prithee Horatio, tell me one thing.

Horatio: What's that my Lord?

Ham: Dost thou think Alexander looked $\mathrm{o}^{\prime}$ this fashion $\mathrm{i}^{\prime}$ the earth?

Hor: E'en so my lord

Ham: To what base uses may we return

Horatio! Why may not imagination trace the

noble dust of Alexander, till he find it stopping

a bung hole?

Hor: 'Twere to consider too curiously, to con-

sider so.

Ham: No, faith. Not a jot; but to follow him

thither with modesty enough, and likelihood to

lead it; as thus: Alexander dies, Alexander

was buried; Alexander returneth into dust; the

dust is earth; of earth we make loam, and why

of that loam, whereto he was converted, might

they not stop a beer-barrel?

Imperious Caesar, dead and turn'd to clay

Might stop a hole to keep the wind away:
O! that that earth, which kept the world in awe,

Should patch a wall to expel the winter's flaw. ${ }^{17}$

No dead body remains intact; the worms (a certain convocation of politic worms-if one is lucky!) or the fire and eventually dust claim it. It is disintegrated, dispersed and may end as the bung in a beer barrel or the mortar in a wall. The alternatives are not burial intact or disintegration. There is simply no alternative which does not involve disintegration.

Given the irrationality of the aim, it is difficult to defend a right to pursue such an aim when it is clear that doing so costs lives.

Hamer and Rivlin's final point is that my account denies moral agents freedom. This is nonsense. Giving people powerful reasons to do something does not deny them freedom. If, persuaded by this they then enact legislation (like that concerning seat belts) it is not the argument that has denied people freedom to contravene the law but the democratic process.

They say:

Why does the fact that there is this unfortunate state of affairs-a person whose organs are failinghave any consequences for what we, as uninvolved parties, not doctors or nurses, have to do?

Why does any unfortunate state of affairs have this effect? Why is there ever an obligation to rescue? Why do we have a health care system set up to remedy "unfortunate states of affairs"? I know that rhetorical questions are not arguments. The arguments I have provided elsewhere ${ }^{16}$; but I am confident that simply asking the questions will show the moral poverty of any person, or any philosophy, that could even ask such a question with a straight face! I have to say that someone who does not see that the remediable suffering of others creates obligations is simply not a moral agent. This is the parable of the good Samaritan. Why did the plight of the man who fell among thieves-"have any consequences for what" the Samaritan, as an uninvolved party, not a doctor or nurse, had to do? Remember he was not "good" because he did what he should have done. The "good" was a reference to the lack of expectation among Jews that Samaritans would be minimally decent.

Then they produce an argument attributed to David Schmidtz who:

imagines that there is a button that, if pushed, will cause all sentient life to painlessly cease to exist. "You will, of course, minimise suffering in the process" 
Schmidtz says, correctly we feel, that this case "shows us that minimising suffering is not the only thing that matters. Nor is it always what matters most".

Well it might show suffering is not the only thing that matters. I have never claimed that it is. What it does not show is that the suffering of others does not sometimes create obligations. The example is, however, polluted by the wrongness of killing the innocent who might want to live despite their suffering. Change the example slightly to something much nearer our case. Imagine that there is a button that, if pushed, will cause all sentient life to painlessly cease to suffer forever. The only cost is that one's own body will not remain intact after one's own eventual painless death. Would there be no obligation to press the button?

I will end, as did Hamer and Rivlin, with a last chilling example. They ask what separates cases where there is an obligation to rescue from organ transplantation and answer as follows:

It is not always terribly clear, but some plausible suggestions are: (1) because the situations are usually emergency or disaster situations, and (2) because they are usually "one offs" - our actions will not set a precedent. (3) They are also situations in which a decision has to be made loften because all will die if we do not allow some to). Everyday tragedies, such as the plight of those in end stage organ failure, are sadly neither extraordinary nor likely to end in the foreseeable future. Thus they are not ones in which we feel a decision need be made-we cannot morally retrieve organs against the donors' and families' wishes.
The implication that everyday tragedies are not examples of the needs of others, which require from us a decision to help, is chilling indeed. Surely all remediable suffering gives us powerful reasons to help, but those reasons having nothing to do with whether the tragedies are "one off"! Question: "why must I help those suffering?" Answer: "because it's only an emergency and its only a "one off". Would such an answer provide anyone with a motive for rescue? The motive, the reason, is surely that when people are threatened and/or are suffering and we can help, we can and should prevent suffering unless the costs of so doing are unreasonably high. And as for the desirability of not setting a precedent ... I am reminded of the immortal F M Cornford's famous lampoon of those who invoke such a principle:

The Principle of the Dangerous Precedent is that you should not now do an admittedly right action for fear you, or your equally timid successors, should not have the courage to do right in some future case . . .. Every public action which is not customary, either is wrong, or, if it is right, is a dangerous precedent. It follows that nothing should ever be done for the first time. ${ }^{18}$

J Med Ethics 2003;29:130-134

\section{Author's affiliations}

John Harris, Institute of Medicine, Law and Bioethics, School of Law, University of Manchester, Manchester M1 3 9PL, UK; john.m.harris@man.ac.uk

\section{REFERENCES}

1 Cooper DKC, Lanza RP. Xeno. Oxford: Oxford University Press, 2000: 7-17.

2 Erin CA, Harris J. An ethical market in human organs. J Med Ethics 2003;29:000-00. Figures from UK Transplant: www.uktransplant.org.uk
3 Hamer CL, Rivlin MM. A stronger policy of organ retrieval from cadaveric donors: some ethical considerations. J Med Ethics 2003;29:000-00.

4 Harris J. In vitro fertilisation: the ethical issues. The Philosophical Quarterly 1983;33:217-38; Harris J. The value of life. London: Routledge \& Kegan Paul, 1985: ch 6 Since then I have made a number of other radical proposals. See Erin CA, Harris J. A monopsonistic market. In: Robinson I, ed. The social consequences of life \& death under high technology medicine. Manchester: Manchester University Press, 1994: 134-57.

5 Most recently I have articulated the details of this challenge in my Law and regulation of retained organs: the ethical issues. Legal Studies 2002;4:527-49.

6 Harris J. Wonderwoman \& Superman. Oxford: Oxford University Press, 1992: ch 5, and Dworkin R. Life's dominion. London: Harper Collins, 1993: ch 7.

7 Harris $\mathrm{J}$. Ethical issues in geriatric medicine. In: Tallis RC, Brockelhurst JC, Fillett $\mathrm{H}$, eds. Textbook of geriatric medicine and gerontology [5th ed]. London: Churchill Livingstone, 1998.

8 I have recently discussed the ethics of postmortem examinations and of retained organs and tissue at some length. In the same place I elaborate the, of necessity rather brief, discussion here of posthumous interests and consent from dead people. See reference 5 .

9 Dworkin R. Life's dominion. London: Harper Collins, 1993: 210-16, and Harris J. Wonderwoman and Superman. Oxford: Oxford University Press, 1992: 100ff. (For example.)

10 See reference 6: Harris J: 100-1.

11 See reference 6: Dworkin R: $201 \mathrm{ff}$.

12 Derek Parfit, Following Jan Narveson defines the person affecting restriction thus: "This part of morality, the part concerned with human wellbeing, should be explained entirely in terms of what would be good or bad for those people whom our acts affect". See Harris J. Reasons and persons. Oxford: Clarendon Press, 1984: 394.

13 See reference 6: Harris J: ch 5: 100-1

14 Dworkin R. Taking rights seriously. London: Duckworth, 1977.

15 Harris J. The welfare of the child. Health Care Analysis 2000;8:27-34. And Harris J. Consent and end of life decisions. J Med Ethics 2003;29:(in press). (For example.)

16 Harris J. Violence \& responsibility. London: Routledge \& Kegan Paul, 1980.

17 Hamlet: act 5, scene 1, lines 194-214. The Arden Shakespeare complete works. Walton on Thames: Thomas Nelson and Sons, 1998

18 Cornford FM. Microcosmographia academica [6th ed]. London: Bowes and Bowes, 1964: 23. 